\title{
Additions to wild seed and fruit fungi 1: The sexual morph of Diaporthe rosae on Magnolia champaca and Senna siamea fruits in Thailand
}

\author{
Perera RH ${ }^{1,2}$, Hyde KD ${ }^{2,3,4}$, Peršoh $D^{5}$, Jones EBG ${ }^{6}$, Liu JK ${ }^{1}$ and Liu ZY ${ }^{1^{*}}$ \\ ${ }^{\text {I} G u i z h o u ~ K e y ~ L a b o r a t o r y ~ o f ~ A g r i c u l t u r a l ~ B i o t e c h n o l o g y, ~ G u i z h o u ~ A c a d e m y ~ o f ~ A g r i c u l t u r a l ~ S c i e n c e s, ~ G u i y a n g, ~}$ \\ Guizhou Province 550006, P.R. China. \\ ${ }^{2}$ Center of Excellence in Fungal Research, Mae Fah Luang University, Chiang Rai 57100, Thailand. \\ ${ }^{3}$ Key Laboratory for Plant Biodiversity and Biogeography of East Asia (KLPB), Kunming Institute of Botany, Chinese \\ Academy of Science, Kunming 650201, Yunnan, China. \\ ${ }^{4}$ World Agroforestry Centre, East and Central Asia, 132 Lanhei Road, Kunming 650201, P.R. China. \\ ${ }^{5}$ Ruhr-Universität Bochum, AG Geobotanik, Gebäude ND 03/170, Universitätsstraße 150, 44801 Bochum, Germany. \\ ${ }^{6}$ Department of Botany and Microbiology, College of Science, King Saud University, P.O. Box: 2455, Riyadh, 1145, \\ Saudi Arabia.
}

Perera RH, Hyde KD, Peršoh D, Jones EBG, Liu JK, Liu ZY 2018 - Additions to wild seed and fruit fungi 1: The sexual morph of Diaporthe rosae on Magnolia champaca and Senna siamea fruits in Thailand. Mycosphere 9(2), 256-270, Doi 10.5943/mycosphere/9/2/7

\begin{abstract}
We are studying seed and fruit fungi in Thailand and made several sexual morph collections of Diaporthe rosae from dried fruits of Magnolia champaca and Senna siamea. The sexual morphs were linked to the asexual morphs based on molecular data, and morphological similarity with the asexual morph produced on PDA. The asexual morph of $D$. rosae was previously reported from a dead pedicel of Rosa sp. (Rosaceae) from the same location as its sexual morph. The sexual morph is characterized by 34-46 $\times 6.7-9 \mu \mathrm{m}$ asci and 10-12.5 $\times 2.8-3.6 \mu \mathrm{m}$, ellipsoidal ascospores. We also provide LSU, ITS, tub2 and tef sequence data of $D$. rosae strains which are deposited in GenBank. The molecular analyses were performed in the ARB software environment and the pipeline is provided as supplementary data.
\end{abstract}

Key words - ARB analysis - Diaporthaceae - saprobes - seed/fruit fungi

\section{Introduction}

Diaporthe is a well-known plant pathogenic genus, but species may also occur as endophytes or saprobes (Udayanga et al. 2011, 2012, 2014b, 2015, Gao et al. 2014, Dissanayake et al. 2017a, b, c). Diaporthe species can be found worldwide on a wide range of host plants (Gao et al. 2014, Dissanayake et al. 2017a, b, c). Dissanayake et al. (2017b) provided an account of species in the genus Diaporthe, listing 171 species with associated molecular data. Thirteen Diaporthe species, including an epitype, have been collected in Thailand, from different hosts and substrates (Udayanga et al. 2012, 2015, Liu et al. 2015, Doilom et al. 2016, Hyde et al. 2016, Dissanayake et al. 2017b, Perera et al. 2018, Wanasinghe et al. 2018).

Phenotypic plasticity, cryptic diversification, and a vast range of host associations of Diaporthe species have resulted in complications with the accurate identification of species within 
the genus (Udayanga et al. 2014a). Recently, the systematic accounts of Diaporthe have progressively used molecular data for delineating and characterising species (Santos \& Phillips 2009, Diogo et al. 2010, Udayanga et al. 2012, 2014b, Gao et al. 2014, Dissanayake et al. 2017a, b, c). However, Udayanga et al. (2014b) revealed the importance of detailed study of existing names and type specimens in Diaporthe, before introducing a new name, to avoid introducing superfluous names.

Diaporthe species associated with economically important crops and ornamentals, and postharvest diseases are well-studied (Farr et al. 2002a, b, Luongo et al. 2011, Udayanga et al. 2011, 2012, 2014b, Thomidis et al. 2013, Dissanayake et al. 2017a, b, c), while knowledge of those on wild fruits and seeds is limited. The aim of this study is to identify the species of Diaporthe on fruits of Magnolia champaca in Thailand. Here we introduce the sexual morph of D. rosae based on molecular data, and similarities in asexual morph characters between our collection and the holotype.

\section{Materials and Methods}

Fruits of Magnolia champaca (and Senna siamea) were collected from Phayao and Chiang Rai Provinces, Thailand during August 2017. Macroscopic and microscopic characters of the specimens were observed in the laboratory. Fungal structures were observed using a Motic dissecting microscope (SMZ 168) and a Nikon ECLIPSE 80i compound microscope. Free hand sections of fungal fruiting bodies were taken and mounted in water and Congo red for microscopic study. Photomicrography was carried out using a Canon 450D digital camera fitted to the microscope. Measurements were made with Tarosoft $(\mathrm{R})$ Image Frame Work software. The images used for illustrating the fungus were processed with Adobe Photoshop CS5 v. 12.0 (Adobe Systems, USA). Single spore colonies were established as described in Chomnunti et al. (2014). Pure cultures were obtained on Potato Dextrose Agar (PDA) and incubated at room temperature of $25^{\circ} \mathrm{C}$. To induce sporulation, cultures were incubated in the dark at $25^{\circ} \mathrm{C}$.

Herbarium specimens were deposited in the Mae Fah Luang University (MFLU) herbarium, Chiang Rai, Thailand. Living cultures were deposited in the Culture Collection at Mae Fah Luang University (MFLUCC). Facesoffungi and Index Fungorum numbers were registered as detailed in Jayasiri et al. (2015) and Index Fungorum (2018).

\section{DNA isolation, amplification and analyses}

Mycelia for DNA extraction were grown on PDA at $25^{\circ} \mathrm{C}$. Genomic DNA was extracted using the Biospin Fungus Genomic DNA Extraction Kit-BSC14S1 (BioFlux ${ }^{\circledR}$, P.R. China) following the manufacturer's protocol. Partial gene sequences were amplified for the 28S large subunit rRNA gene (LSU), the internal transcribed spacer (ITS), beta-tubulin (tub2) and translation elongation factor 1-alpha gene (tef). The primers and PCR conditions are listed in Table 1. PCR was performed in a $25 \mu \mathrm{l}$ reaction volume containing, $12.5 \mu \mathrm{l}$ of $2 \times$ PCR Master Mix (TIANGEN

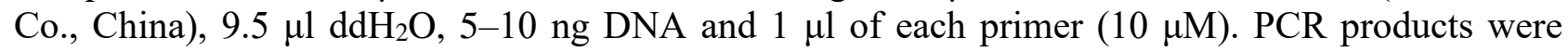
purified and sequenced at Shanghai Sangon Biological Engineering Technology \& Services Co., China. Both directions of the PCR products were sequenced using the same primer pairs as used in PCR amplification. A consensus sequence for each gene region was assembled in ContigExpress (Vector NTI Suite 6.0). Sequences were deposited in GenBank under accession numbers MG906794 (LSU), MG906792 (ITS), MG968953 (tef) and MG968951 (tub2) for D. rosae (MFLUCC 18-0354), and under accession numbers MG906795 (LSU), MG906793 (ITS), MG968952 (tub2) and MG968954 (tef) for D. rosae (MFLUCC 17-2574).

The sequences generated in this study were supplemented with additional sequences downloaded from GenBank (Table 2). Based on BLAST results and preliminary analysis sequences of all strains named as D. miriciae, D. passifloricola and D. ueckerae and related species were incorporated into the final analysis. All alignments were produced with MAFFT v.7.055b (using the E-INS-i alignment strategy, Katoh \& Standley 2013), integrated in ARB program package (v. 6.0.6) (Ludwig et al. 2004), checked and refined where necessary. Maximum likelihood analyses of 
single gene regions: ITS, tef and tub2 were carried out for selected Diaporthe species to compare the topology of the trees and clade stability. Only reliably alignable positions were used for phylogenetic analyses. This included those corresponding to base pairs 25-51, 58-63, 72-104, 105-194, 197-209, and 212-306 of sequence KJ590747 (D. ueckerae) for tef. Of the tub2 alignment, positions $75-174,180-322$, and 328-436 according to sequence KJ610881 were considered. ITS gene trees were based on positions 17-64, 67-92, 98-170, 172-387, and 390-506 according to KJ590726. A combined gene analysis was carried out for concatenated alignment of tef and tub2 sequences.

A maximum likelihood (ML) analysis was performed using RAxML (v.7.7.2, Stamatakis 2006) as implemented in ARB. Support from 1000 bootstrap replicates was mapped on the most likely tree topology, which was found using the GTRGAMMA model of nucleotide substitution. Bayesian inference analysis (BI) was performed using MrBayes (v.3.2.1, Ronquist et al. 2012) as implemented in ARB. GTR $+\mathrm{I}+\mathrm{G}$ was selected as evolutionary model for phylogenetic analyses of tef and tub2 gene regions. Two parallel analyses, each consisting of six Markov Chain Monte Carlo (MCMC) chains, run from random starting trees for 4000000 generations were sampled every 100 generations; resulting in 10000 total trees. The first 2500 trees, representing the burn in phase of the analyses were discarded from each run. The remaining trees were used to calculate posterior probabilities (PP) of the branches in the majority rule consensus tree. Trees were viewed by Xfig v.3.2 patchlevel 5c (Protocol 3.2), and edited using Microsoft PowerPoint 2010.

The ARB database including all phylogenetic trees and corresponding alignments (with information on reliably alignable positions) is freely accessible on the SILVA project website https://www.arb-silva.de/no_cache/download/archive/publications/diaporthe/

Table 1 PCR protocols applied for the analysed loci.

\begin{tabular}{|c|c|c|}
\hline Locus & Primers (Reference) & PCR Conditions \\
\hline LSU & $\begin{array}{l}\text { LR5/LR0R (Vilgalys \& Hester 1990, Rehner \& } \\
\text { Samuels 1994) }\end{array}$ & $\begin{array}{l}\text { a94 }{ }^{\circ} \mathrm{C}: 30 \mathrm{~s}, 55^{\circ} \mathrm{C}: 1 \mathrm{~min} . \\
72^{\circ} \mathrm{C}: 1 \mathrm{~min} .(37 \text { cycles })^{\mathrm{b}}\end{array}$ \\
\hline ITS & ITS5/ITS4 (White et al. 1990) & $\begin{array}{l}{ }^{\mathrm{a}} 94^{\circ} \mathrm{C}: 30 \mathrm{~s}, 55^{\circ} \mathrm{C}: 1 \mathrm{~min} . \\
72^{\circ} \mathrm{C}: 1 \mathrm{~min} .(37 \text { cycles })^{\mathrm{b}}\end{array}$ \\
\hline tef & EF1-728F/ EF1-986R (Carbone \& Kohn 1999) & $\begin{array}{l}{ }^{\mathrm{a} 94}{ }^{\circ} \mathrm{C}: 30 \mathrm{~s}, 48{ }^{\circ} \mathrm{C}: 30 \mathrm{~s}, \\
72{ }^{\circ} \mathrm{C}: 1.30 \text { min. }(35 \text { cycles })^{\mathrm{b}}\end{array}$ \\
\hline$t u b 2$ & Bt2a/Bt2b (Glass \& Donaldson 1995) & $\begin{array}{l}{ }^{\mathrm{a}} 94^{\circ} \mathrm{C}: 30 \mathrm{~s}, 55^{\circ} \mathrm{C}: 50 \mathrm{~s}, \\
72^{\circ} \mathrm{C}: 1 \mathrm{~min} .(35 \text { cycles })^{\mathrm{b}}\end{array}$ \\
\hline
\end{tabular}

anitiation step of $94^{\circ} \mathrm{C}: 3 \mathrm{~min}$

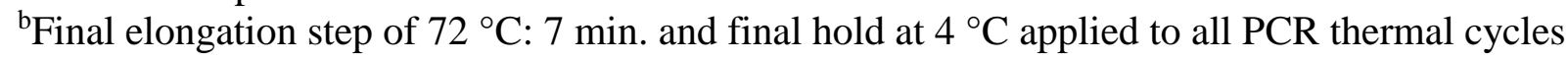

Table 2 GenBank accession numbers of strains included in the study.

\begin{tabular}{lllll}
\hline \multirow{2}{*}{ Species } & \multirow{2}{*}{ Culture collection no. } & \multicolumn{3}{c}{ GenBank no. } \\
\cline { 3 - 5 } & & ITS & tub2 & tef \\
\hline D. batatas & CBS 122.21 (T) & KC343040 & KC344008 & KC343766 \\
D. convolvuli & CBS 124654 (T) & KC343054 & KC344022 & KC343780 \\
D. endophytica & CBS 133811 (T) & KC343065 & KC344033 & KC343791 \\
D. endophytica & LGMF911 & KC343066 & KC344034 & KC343792 \\
D. helianthi & CBS 592.81 (T) & KC343115 & KC344083 & KC343841 \\
D. helianthi & CBS 344.94 & KC343114 & KC344082 & KC343840 \\
D. hordei & CBS 481.92(T) & KC343120 & KC344088 & KC343846 \\
D. kochmani & BRIP 54033(T) & JF431295 & - & JN645809 \\
D. kochmani & BRIP 54034 & JF431296 & - & JN645810 \\
D. kongi & BRIP 54031 (T) & JF431301 & - & JN645797 \\
D. kongi & BRIP 54032 & JF431300 & - & JN645798 \\
\hline
\end{tabular}


Table 2 Continued.

\begin{tabular}{|c|c|c|c|c|}
\hline \multirow{2}{*}{ Species } & \multirow{2}{*}{ Culture collection no. } & \multicolumn{3}{|c|}{ GenBank no. } \\
\hline & & ITS & tub2 & tef \\
\hline D. longicolla & ATCC $60325(\mathrm{~T})$ & KJ590728 & KJ610883 & KJ590767 \\
\hline D. longicolla & FAU644 & KJ590730 & KJ610885 & KJ590769 \\
\hline D. masirevici & BRIP 57892a (T) & KJ197277 & KJ197257 & KJ197239 \\
\hline D. masirevici & BRIP 54256 & KJ197276 & KJ197256 & KJ197238 \\
\hline D. melonis & CBS 507.78 (T) & KC343141 & KC344109 & KC343867 \\
\hline D. melonis & FAU640 & KJ590702 & KJ610858 & KJ590741 \\
\hline D. miriciae & BRIP 54736j (T) & KJ197282 & KJ197262 & KJ197244 \\
\hline D. miriciae & BRIP 56918a & KJ197284 & KJ197264 & KJ197246 \\
\hline D. miriciae & BRIP 55662c & KJ197283 & KJ197263 & KJ197245 \\
\hline D. ovalispora & ZJUD93 (T) & KJ490628 & KJ490449 & KJ490507 \\
\hline D. passifloricola & CBS 141329 (T) & KX228292 & KX228387 & - \\
\hline D. phaseolorum & CBS 116019 & KC343175 & KC344143 & KC343901 \\
\hline D. rosae & MFLUCC 17-2658 (T) & MG828894 & MG843878 & - \\
\hline D. rosae & MFLUCC 17-2574 & MG906793 & MG968952 & MG968954 \\
\hline D. rosae & MFLUCC 18-0354 & MG906792 & MG968951 & MG968953 \\
\hline D. schini & CBS $133181(\mathrm{~T})$ & KC343191 & KC344159 & KC343917 \\
\hline D. schini & LGMF910 & KC343192 & KC344160 & KC343918 \\
\hline D. sojae & FAU635 (T) & KJ590719 & KJ610875 & KJ590762 \\
\hline D. sojae & FAU455 & KJ590712 & KJ610868 & KJ590755 \\
\hline D. sojae & DP0601 & KJ590706 & KJ610862 & KJ590749 \\
\hline D. sojae & MAFF 410444 & KJ590714 & KJ610870 & KJ590757 \\
\hline Diaporthe sp. & LGMF947/CPC 20323 & KC343203 & KC344171 & KC343929 \\
\hline D. subordinaria & CBS $464.90(\mathrm{~T})$ & KC343214 & KC344182 & KC343940 \\
\hline D. tectonendophytica & MFLUCC 13-0471 (T) & KU712439 & KU743986 & KU749367 \\
\hline D. terebinthifolii & CBS $133180(\mathrm{~T})$ & KC343216 & KC344184 & KC343942 \\
\hline D. terebinthifolii & LGMF907 & KC343217 & KC344185 & KC343943 \\
\hline D. thunbergiicola & MFLUCC 12-0033 (T) & KP715097 & - & KP715098 \\
\hline D. ueckerae & FAU656/CBS $139283(\mathrm{~T})$ & KJ590726 & KJ610881 & KJ590747 \\
\hline D. ueckerae & FAU660 & KJ590723 & KJ610878 & KJ590744 \\
\hline D. ueckerae & FAU659 & KJ590724 & KJ610879 & KJ590745 \\
\hline D. ueckerae & FAU658 & KJ590725 & KJ610880 & KJ590746 \\
\hline D. ueckerae & SLHX14 & KY565426 & - & - \\
\hline D. ueckerae & SLHX11 & KY565425 & - & - \\
\hline D. ueckerae & SLHX3 & KY565424 & - & - \\
\hline D. ueckerae & K.L. Chen 034 & - & LC086655 & - \\
\hline D. ueckerae & K.L. Chen 015 & - & LC086654 & - \\
\hline D. unshiuensis & $\begin{array}{l}\text { ZJUD52/ CGMCC } \\
3.17569(\mathrm{~T})\end{array}$ & KJ490587 & KJ490408 & KJ490466 \\
\hline D. unshiuensis & ZJUD50 & KJ490585 & KJ490406 & KJ490464 \\
\hline
\end{tabular}

(T) Ex-type strains

*New isolates are in bold

\section{Results}

Two species of Diaporthe were found on fruits of Magnolia. One species was unambiguously identified as D. collariana according to morphological and molecular data (Perera et al. 2018). A 
second species was reminiscent of $D$. rosae, of which only the asexual morph is currently known. It was therefore analyzed in more detail.

\section{Phylogenetic analyses}

Forty one Diaporthe isolates including our two new strains and an outgroup taxon were selected for the tef data analysis. The tef data set comprised 270 characters with gaps. The best scoring RAxML tree with a final likelihood value of -2151.932507 is presented. The matrix had 178 distinct alignment patterns, with $0.63 \%$ of undetermined characters or gaps. Estimated base frequencies were as follows; $\mathrm{A}=0.187328, \mathrm{C}=0.339338, \mathrm{G}=0.202059, \mathrm{~T}=0.271275$; substitution rates $\mathrm{AC}=1.390930, \mathrm{AG}=4.610159, \mathrm{AT}=1.162314, \mathrm{CG}=1.485311, \mathrm{CT}=$ $3.678796, \mathrm{GT}=1.000000$; gamma distribution shape parameter $\alpha=0.147398$. The $t u b 2$ data set comprised 41 Diaporthe isolates and 352 characters including gaps. The best scoring RAxML tree with a final likelihood value of -1433.994346 is presented. The matrix had 105 distinct alignment patterns, with $0.14 \%$ of undetermined characters or gaps. Estimated base frequencies were as follows; $\mathrm{A}=0.196503, \mathrm{C}=0.353247, \mathrm{G}=0.228837, \mathrm{~T}=0.221413$; substitution rates $\mathrm{AC}=$ 0.915963, $\mathrm{AG}=3.289956, \mathrm{AT}=0.903206, \mathrm{CG}=1.558142, \mathrm{CT}=4.661162, \mathrm{GT}=1.000000$; gamma distribution shape parameter $\alpha=0.421968$. Tree topologies of the ML analyses were similar to the BI. Our two isolates consistently grouped in a monophyletic clade in ML and BI analyses of both $t u b 2$ and tef datasets with high support (Figs 1,2), and moderate support in the tub2 and tef combined tree (Appendix 2). The ITS tree was largely unresolved and the clades lacked reasonable support (Appendix 2).

Diaporthe rosae formed a monophylum with our strains in the tub2 tree and the combined $t u b 2$ and tef tree, while tef sequences of D. rosae were not available for the analysis. Diaporthe miriciae, D. passifloricola and D. ueckerae clustered in close relationship to D. rosae. However, the species differ according to their DNA sequences and morphological characters (Table 3). Furthermore, Diaporthe sp. (LGMF947/CPC 20323), which was isolated from a seed of Glycine max from Brazil, shows close phylogenetic affinities to D. rosae in the tef tree (Fig. 2). The two species (Diaporthe sp. and D. rosae) showed 5 nucleotides differences in the tub2 region, and 3 different nucleotides in the ITS region, while their tef sequences were identical.

\section{Taxonomy}

Diaporthe rosae Samarakoon \& K.D. Hyde

Figs 3, 4

Saprobic on Rosa sp. and, dried fruits of Magnolia champaca and Senna siamea. Visible as raised, black spots or, black necks immerging through the host surface. Sexual morph - Ascomata 260-350 $\mu \mathrm{m}$ high, $210-340 \mu \mathrm{m}$ diam. ( $\bar{x}=260 \times 300 \mu \mathrm{m}, \mathrm{n}=6$ ), immersed in the ectostroma, immersed in the host epidermis, globose to sub-globose, solitary or occur in clusters, black, ostiolate, papillate. Neck $190 \times 435 \mu \mathrm{m}$ diam. Ostiole periphysate. Peridium 8-22 $\mu \mathrm{m}$ wide, comprising 4-10 layers, outer layers heavily pigmented, thin-walled, comprising dark brown cells of textura angularis, inner layers composed of hyaline to brown thin-walled cells of textura angularis. Paraphyses 5.4-8 $\mu \mathrm{m}(\mathrm{n}=10), 2-4$-septate, wide at base, tapering towards the apex, thin walled. Asci 34-46 $\times 6.7-9 \mu \mathrm{m}(\bar{x}=40.5 \times 7.9 \mu \mathrm{m}, \mathrm{n}=20), 8$-spored, unitunicate, clavate to subclavate, straight to slightly curved, sessile, with a J- apical ring. Ascospores 10-12.5 × 2.8-3.6 $\mu \mathrm{m}(\bar{x}=11.1 \times 3.2 \mu \mathrm{m}, \mathrm{n}=30)$, overlapping uniseriate to biseriate, 1 -septate, constricted at the septum, often tetra-guttulate, ellipsoidal, straight, hyaline, without appendages or a mucilaginous sheath. Asexual morph on PDA - Conidiomata pycnidial or multiloculate, scattered, globose or irregular, black. Peridium consisting brown cells of textura angularis in surface view. Conidial mass globose, white to pale-yellow. Paraphyses absent. Conidiophores $10-63 \times 1.4-2.7 \mu \mathrm{m}(\bar{x}$ $=36.4 \times 2 \mu \mathrm{m}), 2-3$-septate, branched, densely aggregated, cylindrical, straight to sinuous rarely reduced to conidiogenous cells, hyaline, smooth-walled. Alpha conidiogenous cells 8-23 $\times$ 0.7-3 $\mu \mathrm{m}(\bar{x}=15.4 \times 1.8 \mu \mathrm{m})$ phialidic, subcylindrical, sometimes ampulliform, slightly tapering towards the apex, hyaline, with visible periclinal thickening, and a flared collarette. Alpha conidia 
5-7 $\times 2-3.1 \mu \mathrm{m}(\bar{x}=5.9 \times 2.5 \mu \mathrm{m})$, enteroblstic, ovate to ellipsoidal, base obtuse to subtruncate, aseptate, straight, bi-guttulate, hyaline, smooth-walled. Beta conidiogenous cells 4.1-22.6 × 1.3$4.2 \mu \mathrm{m}(\bar{x}=16.6 \times 2 \mu \mathrm{m})$ phialidic, subcylindrical, tapering towards the apex, hyaline, with periclinal thickening, and a flared collarette. Beta conidia 18-28 $\times 0.9-1.3 \mu \mathrm{m}(\bar{x}=22.3-1.1 \mu \mathrm{m})$, fusiform to hooked, aseptate, hyaline, smooth-walled. Gamma conidia not observed.

Culture characteristics - Colonies on PDA, reaching $40 \mathrm{~mm}$ diam. after 2 weeks at $25^{\circ} \mathrm{C}$, flat, circular, margin entire, white with radially arranged minute mycelium clots later becoming pale yellow, reverse whitish, azonate. Odour not pronounced. Sporulated on PDA after 2 months incubation period in dark, at $25^{\circ} \mathrm{C}$.

Material examined - THAILAND, Chiang Rai Province, Mae Fah Luang University premises, on dried fruits and pedicels of Magnolia champaca (L.) Baill. ex Pierre (Magnoliaceae), 17 August 2017, S. Boonmee, Fruit 5 (MFLU 18-0186); dry culture, MFLU 18-0515; living culture, MFLUCC 18-0354; ibid. Phayao Province, Pong, Pha Chang Noi, dried pods of Senna siamea (Lam.) Irwin et Barneby (Fabaceae), 04 August 2017, R.H. Perera, PH-FB 1 (MFLU 180187), living culture, MFLUCC 17-2574.

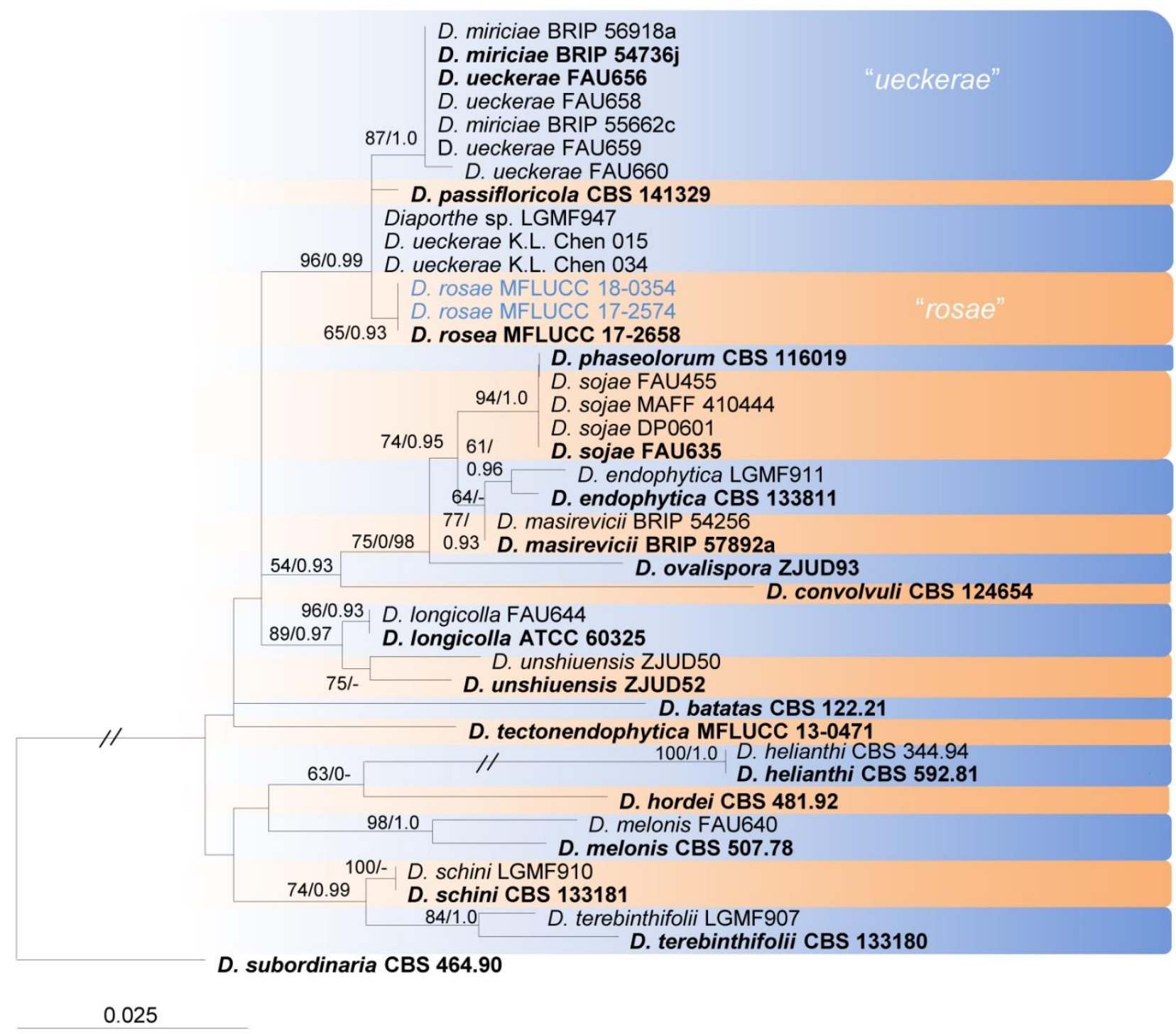

Figure 1 - Phylogram generated from maximum likelihood analysis based on $t u b 2$ sequences of selected Diaporthe species. Maximum likelihood bootstrap support (ML $\geq 50 \%$ ) and posterior probabilities $(\mathrm{PP} \geq 0.90)$ from Bayesian inference analysis are indicated respectively near the nodes. The ex-type strains are in bold and new isolates in blue. The scale bar indicates 0.025 nucleotide changes per site. The tree is rooted with Diaporthe subordinaria. 


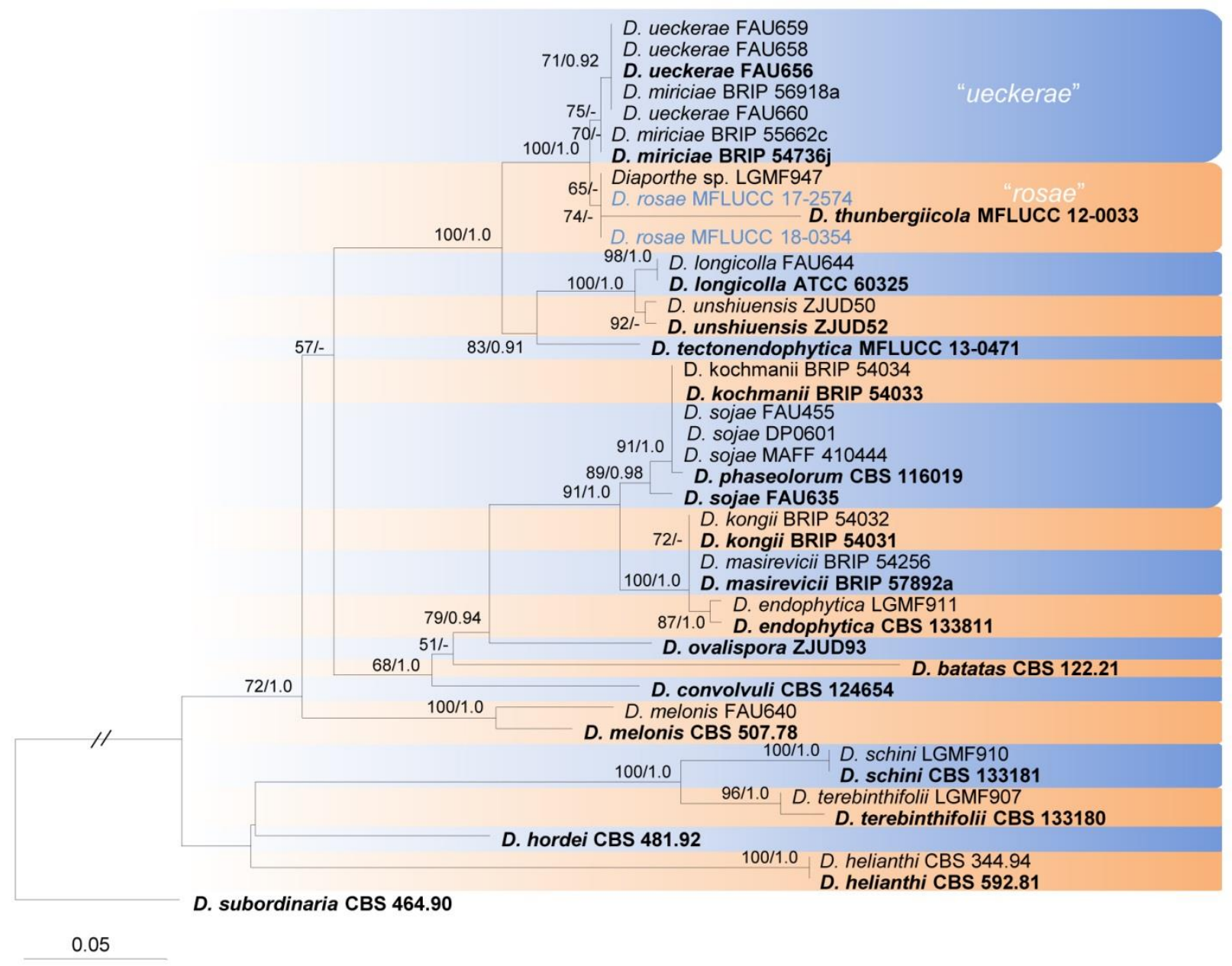

Figure 2 - Phylogram generated from maximum likelihood analysis based on tef sequence data of selected Diaporthe species. Maximum likelihood bootstrap support (ML $\geq 50 \%$ ) and posterior probabilities $(\mathrm{PP} \geq 0.90)$ from Bayesian inference analysis are indicated respectively near the nodes. The ex-type strains are in bold and new isolates in blue. The scale bar indicates 0.05 nucleotide changes per site. The tree is rooted with Diaporthe subordinaria.

Notes - Our two new isolates grouped with the ex-type strain of D. rosae (MFLUCC 172658), which was collected from Rosa sp. (Rosaceae) in Chiang Rai Province, Thailand (Fig. 1) (Wanasinghe et al. 2018). The asexual morph of one of the new strains (MFLUCC 18-0354) produced on PDA is similar to that of the holotype of D. rosae (MFLU 17-1550). DNA sequences of $D$ rosae and strains (MFLUCC 18-0354 and MFLUCC 17-2574) differed in 2 positions of the ITS region, while tub2 sequences were identical. Sequence data of the tef region were not available for the ex-type of $D$. rosae for the comparison. Neither molecular nor morphological data accordingly allow delimiting the new collection from $D$. rosae. It is therefore reported here as the sexual morph of $D$. rosae.

\section{Discussion}

In this study, we used the ARB software environment to analyze the sequence data related to our collection and the pipeline is provided as the Supplementary Data to this paper (Appendix 1). Sequence heterogeneity of ITS has been observed earlier within the same species of Diaporthe, even within the same geographic region and the same host by different authors (Farr et al. 2002a, b, Santos et al. 2010; Udayanga et al. 2014a). The difference of 2 nucleotides in the ITS region 
Table 3 Comparison of our new collection with holotype of Diaporthe rosae, and related species

\begin{tabular}{|c|c|c|c|c|c|}
\hline \multirow[t]{2}{*}{ Characters } & $\begin{array}{l}\text { Diaporthe rosae Samarakoon } \\
\text { \& K.D. Hyde }\end{array}$ & $\begin{array}{l}\text { Diaporthe rosae Samarakoon } \\
\text { \& K.D. Hyde }\end{array}$ & $\begin{array}{l}\text { Diaporthe ueckerae } \\
\text { Udayanga \& Castl. } 2014\end{array}$ & $\begin{array}{l}\text { Diaporthe miriciae } \text { R.G. } \\
\text { Shivas, S.M. Thomps. \& } \\
\text { Y.P. Tan } 2015\end{array}$ & $\begin{array}{l}\text { Diaporthe passiflorae Crous } \\
\text { \& L. Lombard } 2012\end{array}$ \\
\hline & Wanasinghe et al. (2018) & This study & Udayanga et al. (2015) & Thompson et al. (2015) & Crous et al. (2012) \\
\hline Lifestyle and host & $\begin{array}{l}\text { Saprobic on dead pedicel of } \\
\text { Rosa sp./ Thailand }\end{array}$ & $\begin{array}{l}\text { Saprobic on dried fruits of } \\
\text { Magnolia champaca and Senna } \\
\text { siameal Thailand }\end{array}$ & Cucumis melo/ USA & $\begin{array}{l}\text { Helianthus annuus, Vigna } \\
\text { radiata, Glycine maxl } \\
\text { Australia }\end{array}$ & $\begin{array}{l}\text { Passiflora edulis/ South } \\
\text { America }\end{array}$ \\
\hline Conidiomata & $\begin{array}{l}\text { Multiloculate, scattered on } \\
\text { PDA }\end{array}$ & $\begin{array}{l}\text { Multiloculate or pycnidial, } \\
\text { scattered on PDA }\end{array}$ & $\begin{array}{l}\text { Pycnidial, globose, } 150-200 \\
\mu \mathrm{m} \text { diam., ostiolate with necks }\end{array}$ & $\begin{array}{l}\text { Pycnidial or multilocular, } \\
\text { ostiolate with necks }\end{array}$ & $\begin{array}{l}\text { Pycnidial, globose, } 300 \mu \mathrm{m} \\
\text { diam. }\end{array}$ \\
\hline Conidiophores & $\begin{array}{l}\text { Present, sometimes reduced to } \\
\text { conidiogenous cells }\end{array}$ & $\begin{array}{l}\text { Present, 2-3-septate, rarely } \\
\text { reduced to conidiogenous cells, } \\
\text { cylindrical, straight to sinuous }\end{array}$ & $\begin{array}{l}\text { Present, unbranched, } \\
\text { ampulliform, long, slender }\end{array}$ & $\begin{array}{l}\text { Reduced to conidiogenous } \\
\text { cells or } 1-2 \text {-septate }\end{array}$ & $\begin{array}{l}\text { Present, 2-3-septate, } \\
\text { branched, densely } \\
\text { aggregated, cylindrical, } \\
\text { straight to sinuous }\end{array}$ \\
\hline $\begin{array}{l}\text { Conidiophore } \\
\text { dimension }(\mu \mathrm{m})\end{array}$ & $10-19 \times 1.9-3.3$ & $10-63 \times 1.4-2.7$ & $(9-) 12-28(-30) \times 1.5-2.5$ & $10-20 \times 1.5-3$ & $20-30 \times 2.5-4$ \\
\hline $\begin{array}{l}\text { Alpha and beta } \\
\text { conidiogenous cells }\end{array}$ & $\begin{array}{l}\text { Phialidic, ampulliform, } \\
\text { slightly tapering towards the } \\
\text { apex with periclinal } \\
\text { thickening, with a flared } \\
\text { collarette }\end{array}$ & $\begin{array}{l}\text { Phialidic, subcylindrical, } \\
\text { sometimes ampulliform, } \\
\text { slightly tapering towards the } \\
\text { apex, with periclinal } \\
\text { thickening, and a flared } \\
\text { collarette }\end{array}$ & $\begin{array}{l}\text { Phialidic, cylindrical, } \\
\text { terminal, slightly tapering } \\
\text { towards apex }\end{array}$ & Cylindrical to obclavate & $\begin{array}{l}\text { Phialidic, cylindrical, } \\
\text { terminal and lateral }\end{array}$ \\
\hline $\begin{array}{l}\text { Conidiogenous cells } \\
\text { dimension }(\mu \mathrm{m})\end{array}$ & $\begin{array}{l}7-13 \times 1-2.5 \text { (Alpha) } \\
7.7-15 \times 1.2-2.3 \text { (Beta) }\end{array}$ & $\begin{array}{l}8-23 \times 0.7-3(\text { Alpha }) \\
4.1-22.6 \times 1.3-4.2(\text { Beta })\end{array}$ & 0.5-1 (diam.) & $10-20 \times 1.5-3$ & $7-15 \times 1.5-2.5$ \\
\hline Alpha conidia & $\begin{array}{l}\text { Ovate to ellipsoidal, base } \\
\text { subtruncate, bi- biguttulate, } \\
\text { aseptate, hyaline, smooth- } \\
\text { walled }\end{array}$ & $\begin{array}{l}\text { Ovate to ellipsoidal, base } \\
\text { obtuse to subtruncate, bi- } \\
\text { guttulate, aseptate, hyaline, } \\
\text { smooth, smooth-walled }\end{array}$ & $\begin{array}{l}\text { Abundant, aseptate, hyaline, } \\
\text { smooth, ellipsoidal, often } \\
\text { biguttulate, base subtruncate }\end{array}$ & $\begin{array}{l}\text { Abundant, aseptate, hyaline, } \\
\text { fusiform to oval, rounded at } \\
\text { the apex, narrowed at the } \\
\text { base }\end{array}$ & $\begin{array}{l}\text { Aseptate, hyaline, smooth, } \\
\text { multi-guttulate, fusoid to } \\
\text { ellipsoid, tapering } \\
\text { towards both ends, straight, } \\
\text { apex subobtuse, base } \\
\text { subtruncate }\end{array}$ \\
\hline $\begin{array}{l}\text { Alpha conidia } \\
\text { dimension }(\mu \mathrm{m})\end{array}$ & $5.5-7.5 \times 2-3$ & $5-7 \times 2-3.1$ & $(6-) 6.4-8.2(-8.6) \times(2-) 2.3-3$ & $6-7.5(-9) \times 2-2.5(-3)$ & $\begin{array}{l}(5.5-) 6-7(-8) \times(2-) 2.5-3(- \\
3.5)\end{array}$ \\
\hline Beta conidia & Fusiform to hooked & Fusiform to hooked & Not observed & $\begin{array}{l}\text { Scattered or in groups } \\
\text { amongst the alpha conidia, } \\
\text { flexuous to hamate, hyaline }\end{array}$ & $\begin{array}{l}\text { Spindle-shaped, aseptate, } \\
\text { apex acutely rounded, base } \\
\text { truncate, tapering from lower } \\
\text { third towards Apex, curved }\end{array}$ \\
\hline $\begin{array}{l}\text { Beta conidia } \\
\text { dimension }(\mu \mathrm{m})\end{array}$ & $\begin{array}{l}12.5-18 \times 1-2 \text { (on natural } \\
\text { substrate) }\end{array}$ & & - & $20-35 \times 1.0-1.5$ & $(14-) 16-18(-20) \times 1.5(-2)$ \\
\hline & $12.6-21.1 \times 0.7-1.2$ (on PDA) & $18-28 \times 0.9-1.3($ on PDA $)$ & & & \\
\hline
\end{tabular}




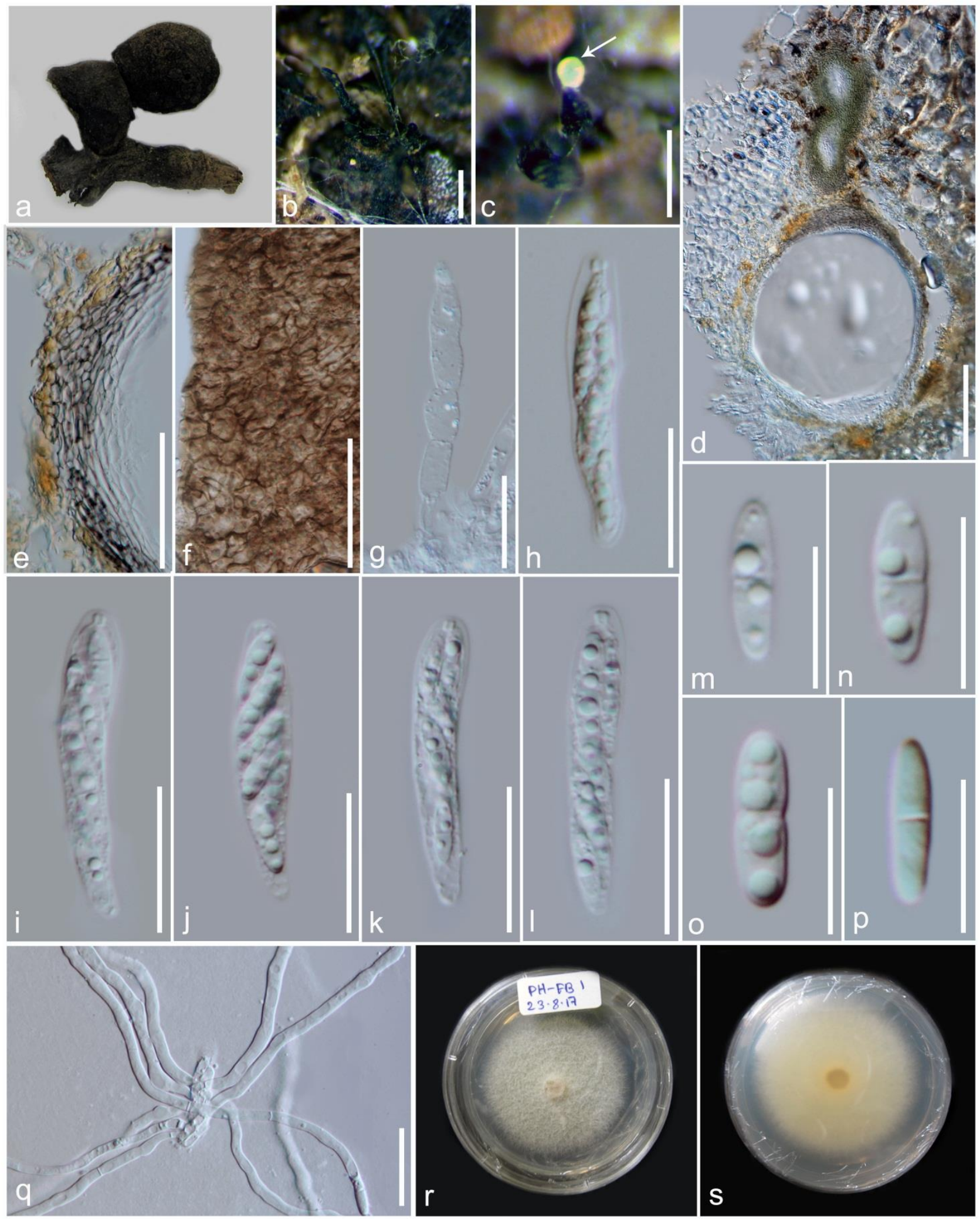

Figure 3 - Diaporthe rosae (MFLU 18-0186) a Herbarium material. b, c Ascomata on host substrate (white arrow: ascospores mass on the neck). d Section through ascoma. e Section through the peridium. f Surface view of the peridium. g Paraphyses. $h-1$ Asci. $m-p$ Ascospores. $q$ Germinating ascospores. Bars $-\mathrm{b}, \mathrm{c}=200 \mu \mathrm{m}, \mathrm{d}=100 \mu \mathrm{m}, \mathrm{e}, \mathrm{f}=50 \mu \mathrm{m}, \mathrm{g}-\mathrm{l}=20 \mu \mathrm{m}, \mathrm{m}-\mathrm{p}=10, \mathrm{q}$ $=20 \mu \mathrm{m}$. 

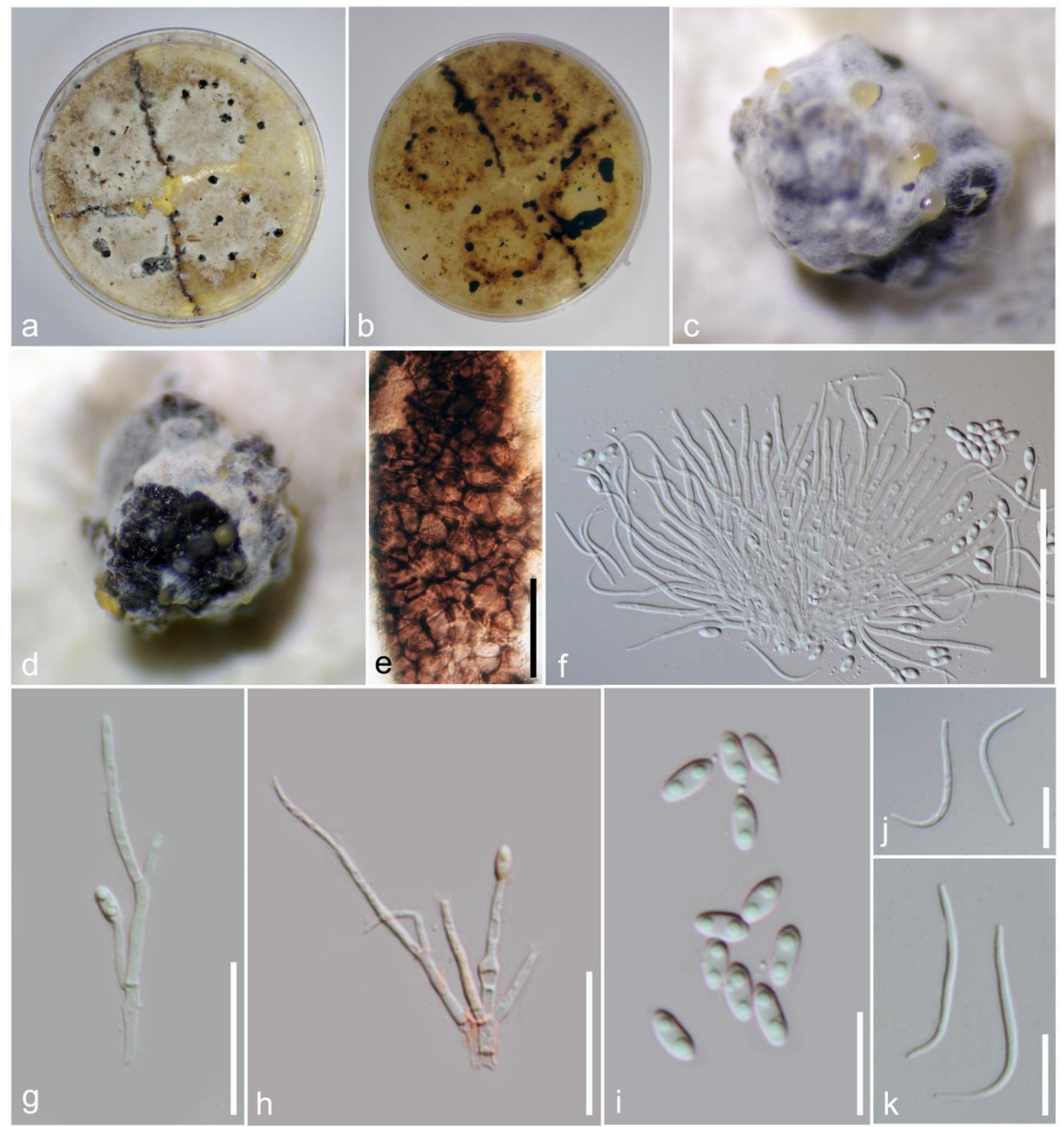

Figure 4 - Diaporthe rosae (MFLU 18-0515, asexual morph on PDA) a, b Sporulation on PDA. c, $\mathrm{d}$ Conidioma on PDA. e Surface view of the peridium. $\mathrm{f}$ Conidiophores with alpha and beta conidia. g, h Conidiophores with alpha conidia. i Alpha conidia. j, k Beta conidia. Bars $-\mathrm{b}, \mathrm{c}=200$ $\mu \mathrm{m}, \mathrm{d}=100 \mu \mathrm{m}, \mathrm{e}, \mathrm{f}=50 \mu \mathrm{m}, \mathrm{g}-\mathrm{l}=20 \mu \mathrm{m}, \mathrm{m}-\mathrm{p}=10, \mathrm{q}=20 \mu \mathrm{m}$.

between our collection and the asexual morph of $D$. rosae is therefore in the range of intraspecific variability within the genus.

Diaporthe miriciae and D. ueckerae strains only form a monophyletic clade together in the tub2, tef and combined tef and tub2 analyses (Figs 1, 2, Appendix 2), 'ueckerae' Clade). Furthermore, ITS, tef and tub2 sequence data of their ex-types (BRIP 54736j and FAU656) are almost identical except for $1 \mathrm{bp}$ difference in the tef region. When considering other D. miriciae (BRIP 56918a, BRIP 55662c) and D. ueckerae (FAU660, FAU659, FAU658) strains, a maximum difference of 3 nucleotides is found within the clade. Diaporthe miriciae and D. ueckerae also share similar morphological characters (Table 3). Even though those similarities are in the same range as for $D$. rosae and the new collections, we refrain from describing our collection as a new species. We agree with Udayanga et al (2014a) that such differences most likely represent 
intraspecific variation. Another two strains putatively named as D. ueckerae (K.L. Chen 015 and K.L. Chen 034) are unrelated to the main 'ueckerae' clade (Fig. 1). They showed 4 nucleotide substitutions in tub2 region to the D. ueckerae species in the main clade. However, no other gene regions or morphological features are available for comparison.

One problematic sequence of D. thunbergiicola (MFLUCC 12-0033) clusters with long branches and its phylogenetic position is conflicting notably between ITS and tef trees (Fig. 2, Appendix 2). Re-sequencing of the isolate of $D$. thunbergiicola would be required to finally confirm its phylogenetic position. While we did not exclude D. thunbergiicola (MFLUCC 12-0033) from our analysis, we do not consider our results strong evidence for the species being related to the $D$. rosae clade.

\section{Acknowledgements}

The Research of Featured Microbial Resources and Diversity Investigation in Southwest Karst area (Project No. 2014FY120100) is thanked for financial support. Kevin D. Hyde thanks the Chinese Academy of Sciences, project number 2013T2S0030, for the award of a Visiting Professorship for Senior International Scientists at Kunming Institute of Botany. This work was also supported by the Thailand Research Fund, 'The future of specialist fungi in a changing climate: baseline data for generalist and specialist fungi associated with ants, Rhododendron species and Dracaena species' (Project No. DBG6080013).

\section{References}

Carbone I, Kohn LM. 1999 - A method for designing primer sets for speciation studies in filamentous ascomycetes. Mycologia 91, 553-556.

Chomnunti P, Hongsanan S, Aguirre-Hudson B, Tian Q et al. 2014 - The sooty moulds. Fungal Diversity 66, 1-36.

Crous PW, Summerell BA, Shivas RG, Burgess TI et al. 2012 - Fungal Planet description sheets: 107-127. Persoonia: Molecular Phylogeny and Evolution of Fungi. 28, 138-182.

Diogo ELF, Santos JM, Phillips AJL. 2010 - Phylogeny, morphology and pathogenicity of Diaporthe and Phomopsis species on almond in Portugal. Fungal Diversity 44, 107-115.

Doilom M, Dissanayake AJ, Wanasinghe DN, Boonmee S et al. 2016 - Microfungi on Tectona grandis (teak) in Northern Thailand. Fungal Diversity 82, 107-182.

Dissanayake AJ, Camporesi E, Hyde KD, Zhang W. et al. 2017a-Molecular phylogenetic analysis reveals seven new Diaporthe species from Italy. Mycosphere 8, 853-877.

Dissanayake AJ, Phillips AJL, Hyde KD, Yan JY et al. 2017b - The current status of species in Diaporthe. Mycosphere 8, 1106-1156.

Dissanayake AJ, Zhang W, Liu M, Hyde KD et al. 2017c - Diaporthe species associated with peach tree dieback in Hubei, China. Mycosphere 8, 533-549.

Farr DF, Castlebury LA, Rossman AY. 2002a - Morphological and molecular characterization of Phomopsis vaccinii and additional isolates of Phomopsis from blueberry and cranberry in the eastern United States. Mycologia 94, 494-504.

Farr DF, Castlebury LA, Rossman AY, Putnam ML. 2002b - A new species of Phomopsis causing twig dieback of Vaccinium vitisidaea (lingonberry). Mycological Research 106:745-752.

Gao YH, Sun W, Su YY, Cai L. 2014 - Three new species of Phomopsis in Gutianshan Nature Reserve in China. Mycological Progress 13, 111-121.

Glass NL, Donaldson GC. 1995 - Development of primer sets designed for use with the PCR to amplify conserved genes from filamentous ascomycetes. Applied and Environmental Microbiology 61, 1323-1330.

Hyde KD, Hongsanan S, Jeewon R, Bhat DJ et al. 2016 - Fungal diversity notes 367-492, taxonomic and phylogenetic contributions to fungal taxa. Fungal Diversity 80:1-270.

Index Fungorum. 2018 - www.indexfungorum.org. 
Jayasiri SC, Hyde KD, Ariyawansa HA, Bhat J et al. 2015 - The Faces of Fungi database: fungal names linked with morphology, phylogeny and human impacts. Fungal Diversity 74, 3-18.

Katoh K, Standley D.M. 2013 - MAFFT multiple sequence alignment software version 7: improvements in performance and usability, Molecular Biology and Evolution 30,772-780.

Liu JK, Hyde KD, Jones EBG, Ariyawansa HA et al. 2015 - Fungal diversity notes 1-110, taxonomic and phylogenetic contributions to fungal species. Fungal Diversity 72, 1-197.

Ludwig W, Strunk O, Westram R, Richter L et al. 2004 - ARB: a software environment for sequence data. Nucleic Acids Research 32, 1363-1371.

Luongo L, Santori A, Riccioni L, Belisario A. 2011 - Phomopsis sp. associated with post-harvest fruit rot of kiwifruit in Italy. Journal of Plant Pathology 93, 205-209.

Perera RH, Hyde KD, Dissanayake AJ, Jones EB et al. 2018 - Diaporthe collariana sp. nov., with prominent collarettes associated with Magnolia champaca fruits in Thailand. Studies in Fungi, in press.

Rehner SA, Samuels GJ. 1994 - Taxonomy and phylogeny of Gliocladium analysed from nuclear large subunit ribosomal DNA sequences. Mycological Research 98, 625-634.

Ronquist F, Teslenko M, Van der Mark P, Ayres DL et al. 2012 - MrBayes v. 3.2: efficient Bayesian phylogenetic inference and model choice across a large model space. Systematic Biology 61, 539-542.

Santos JM, Correia VG, Phillips AJL. 2010 - Primers for mating-type diagnosis in Diaporthe and Phomopsis: their use in teleomorph induction in vitro and biological species definition. Fungal Biology 114, 255-270.

Santos JM, Phillips AJL. 2009 - Resolving the complex of Diaporthe (Phomopsis) species occurring on Foeniculum vulgare in Portugal. Fungal Diversity 34, 111-125.

Stamatakis A. 2006 - RAxML-VI-HPC: maximum likelihood-based phylogenetic analyses with thousands of taxa and mixed models, Bioinformatics 22, 2688-2690.

Thomidis T, Exadaktylou E, Chen S. 2013 - Diaporthe neotheicola, a new threat for kiwi fruit in Greece. Crop Protection 47, 35-40.

Thompson SM, Tan YP, Shivas RG, Neate SM et al. 2015 - Green and brown bridges between weeds and crops reveal novel Diaporthe species in Australia. Persoonia: Molecular Phylogeny and Evolution of Fungi 35, 39-49.

Udayanga D, Castlebury LA, Rossman AY, Chukeatirote E et al. 2014a - Insights into the genus Diaporthe: phylogenetic species delimitation in the D. eres species complex. Fungal Diversity 67, 203-229.

Udayanga D, Castlebury LA, Rossman AY, Chukeatirote E et al. 2015 - The Diaporthe sojae species complex, phylogenetic re-assessment of pathogens associated with soybean, cucurbits and other field crops. Fungal Biology 119, 383-407.

Udayanga D, Castlebury LA, Rossman AY, Hyde KD. 2014b - Species limits in Diaporthe: molecular re-assessment of $D$. citri, D. cytosporella, D. foeniculina and D. rudis. Persoonia $32,83-101$.

Udayanga D, Liu X, McKenzie EHC, Chukeatirote E et al. 2011 . The genus Phomopsis: biology, applications, species concepts and names of common phytopathogens. Fungal Diversity 50, 189-225.

Udayanga D, Liu X, MCkenzie EHC, Chukeatirote E et al. 2012 - Multi-locus phylogeny reveals three new species of Diaporthe from Thailand. Cryptogamie Mycologie 33, 295-309.

Vilgalys R, Hester M. 1990 - Rapid genetic identification and mapping of enzymatically amplified ribosomal DNA from several Cryptococcus species. The Journal of Bacteriology 172, 42384246.

Wanasinghe DN, Phukhamsakda C, Hyde KD, Jeewon R et al. 2018 - Fungal diversity notes 709839: taxonomic and phylogenetic contributions to fungal taxa with an emphasis on fungi on Rosaceae. Fungal Diversity 89, 1-236.

White TJ, Bruns T, Lee S, Taylor J. 1990 - Amplification and direct sequencing of fungal ribosomal RNA genes for phylogenetics. In: Innis MA, Gelfand DH, Sninsky JJ, White TJ 
(eds), PCR Protocols: a guide to methods and applications. Academic Press, New York 315322.

\section{Appendix 1: Supplementary information to manuscript}

\section{Phylogenetic analyses of multi gene alignments using ARB}

1) ARB (http://www.arb-home.de/) was installed on a QIIME 2 Core VirtualBox Image (v 2017.12, https://qiime2.org/), on which libxm4 and Xfig had been installed previously.

2) A new ARB database was created using the ITS sequences downloaded from GenBank (https://www.ncbi.nlm.nih.gov) in GenBank format.

- Sequences were imported into the alignment "ali_ITS"

- The newly created import filter, "GB_MFU.ift" (https://www.arbsilva.de/no_cache/download/archive/imp_exp_filters/), was applied to import a maximum of sequence associated information.

3) The newly generated sequences were imported in FASTA format (File > Import > Import from external format).

4) The sequence accession number was preserved.

- The accession was copied to new field called "Acc_ITS"

i. Sequences with entries in the ali_ITS/data field were searched (Species > Search and query) and the accession numbers were copied using "More functions > Modify Fields of Listed Species" in the "SEARCH and QUERY" window.

5) Imported ITS sequences were aligned using MAFFT (Sequences > Align Sequences > Mafft).

6) A selected sequence was copied to a new 'species' called 'filter' and used as a filter sequence for phylogenetic analyses.

- Positions in the newly created filter sequence, which correspond to ambiguously aligned regions were replaced by Gap symbols ("“-”).

7) Successive import of sequences from other genes

- A new alignment was created (Sequence > Sequennce/Alignment Admin) for each additional gene (ITS, tub2 and tef); ie. 'ali_ITS', 'ali_tub2' and 'ali_tef, respectively, and specified appropriately.

- Reference sequences were imported (File > Import > Import from external format) in GenBank format and using the filter "GB_MFU.ift".

- Newly obtained sequences were imported in FASTA format and using the filter "fasta.ift".

- Sequence Accession numbers were copied to the corresponding field, i.e. 'Acc_ITS', 'Acc_tub2' and 'Acc_tef', respectively.

- Newly imported sequences were aligned using MAFFT.

- A filter sequence, always called 'filter', was created and modified appropriately.

8) Merging of sequences

- A new field ("individual") was created (Species $>$ Database fields admin $>$ create fields...)

- Strain or specimen Ids were copied (using "More functions > Modify Fields of Listed Species" in the "SEARCH and QUERY" window) to the field "individual" and curated.

- Expert mode was enabled (Properties > Toggle expert mode).

- Sequence of the same individual were merged (Species > Merge Species > Create merged species from similar species) using entries in the database field "individual" as identifier.

- The newly created field "merged_species" was modified by adding a "1" to those individuals (strain or specimens) which are only represented by a single sequence. 
- Database entries with single sequences were deleted; i.e. species having no entry in the "merged_species" field were searched (Species $>$ Search and query) and deleted (Delete Listed).

9) Calculating phylogenetic trees using RAxML.

- Only positions in which the filter sequence has no Gap (“-”) were considered for phylogenetic reconstructions.

- The resulting trees were renamed.

- To assure traceability of the analyses, the alignment (including the filter sequence) underlying the phylogenetic tree was copied to a new alignment, which was renamed including the name of the corresponding tree.

10) Calculating multi-gene phylogenies.

- Single gene alignments (including the filter sequences) were concatenated (Sequence > Concatenate Sequences/Alignments).

- Phylogenetic trees were calculated as detailed above based on the positions specified by the filter sequence.

- Trees were renamed and the underlying alignment copied to a correspondingly named alignment for documentation.

\section{Appendix 2}

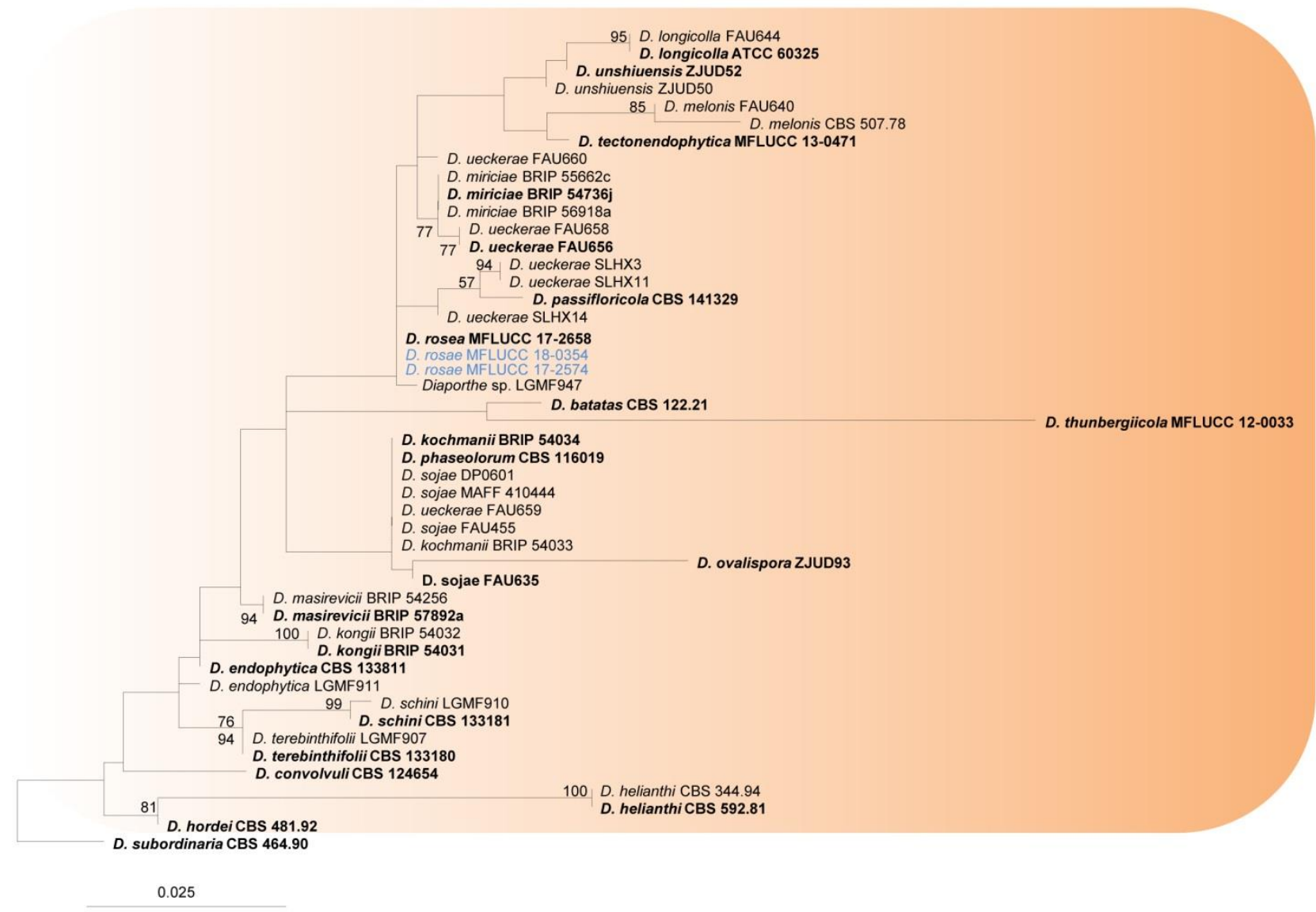

Figure 1 - Phylogram generated from maximum likelihood analysis based on ITS sequences of selected Diaporthe species. Maximum likelihood bootstrap support values (ML $\geq 50 \%$ ) are indicated near the nodes. The ex-type strains are in bold and new isolates in blue. The scale bar indicates 0.025 nucleotide changes per site. The tree is rooted with Diaporthe subordinaria. 


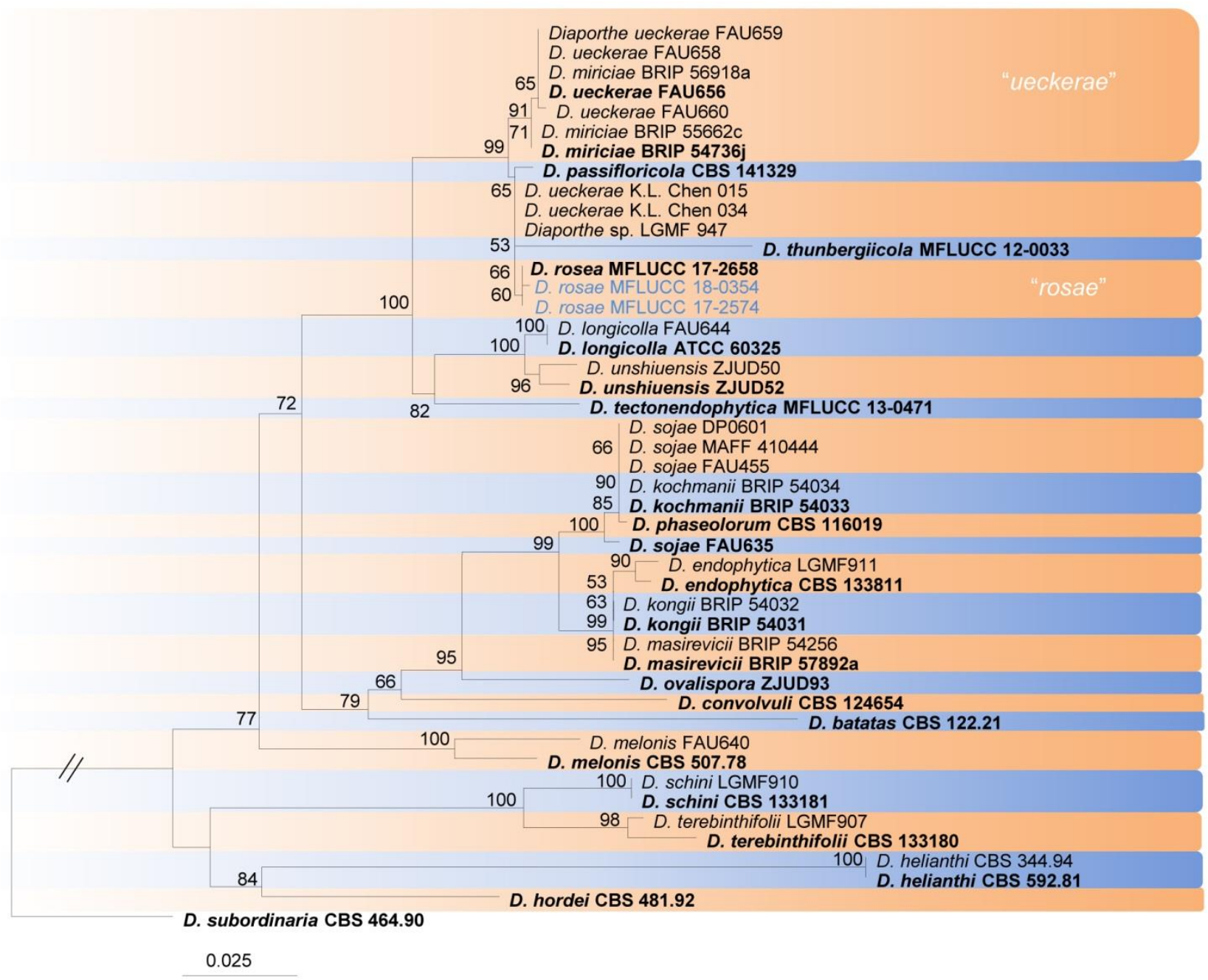

Figure 2 - Phylogram generated from maximum likelihood analysis based on combined tef and tub2 sequence data of selected Diaporthe species. Maximum likelihood bootstrap support (ML $\geq 50 \%)$ is indicated near the nodes. The ex-type strains are in bold and new isolates in blue. The scale bar indicates 0.025 nucleotide changes per site. The tree is rooted with Diaporthe subordinaria. 